Review

\title{
Stem cells and Bronchopulmonary Dysplasia - The five questions: Which cells, when, in which dose, to which patients via which route?
}

\author{
Martin Mueller ${ }^{\mathrm{a}, \mathrm{b}, \mathrm{c}, *}$, Boris W. Kramer ${ }^{\mathrm{d}, \mathrm{e}, \mathrm{f}}$ \\ a Department of Obstetrics and Gynecology, University Hospital Bern, Bern, Switzerland \\ ${ }^{\mathrm{b}}$ Department of Obstetrics, Gynecology, and Reproductive Sciences, Yale University School of Medicine, New Haven, CT, USA \\ ${ }^{\mathrm{c}}$ Department of Clinical Research, University of Bern, Bern, Switzerland \\ ${ }^{\mathrm{d}}$ Department of Pediatrics, Maastricht University Medical Center (MUMC), Maastricht, The Netherlands \\ ${ }^{\text {e }}$ School for Mental Health and Neuroscience, Maastricht University, Maastricht, The Netherlands \\ ${ }^{\mathrm{f}}$ School of Oncology and Developmental Biology (GROW), Maastricht, The Netherlands
}

\section{EDUCATIONAL AIMS}

The reader will come to:

- Understand the definition of stem cells.

- Understand different sorts and sources of stem cells.

- Understand the basic concept of stem cell therapy.

- Appreciate the use of stem cells as a promising new therapy for the prevention of the BPD.

- Realise that testing in clinical medicine is happening, although essential questions about efficacy and ethics remain to be clarified.

\section{A R T I C L E I N F O}

\section{Keywords:}

Bronchopulmonary dysplasia

mesenchymal stem cell transplantation

paracrine immunomodulation

physiologic actions

outcomes

\begin{abstract}
S U M M A R Y
Preterm birth is the leading cause of death in newborns and children. Despite advances in perinatology, immature infants continue to face serious risks such chronic respiratory impairment from bronchopulmonary dysplasia (BPD). Current treatment options are insufficient and novel approaches are desperately needed. In recent years stem cells have emerged as potential candidates to treat BPD with mesenchymal stem/stromal cells (MSCs) being particularly promising. MSCs originate from several stem cell niches including bone marrow, skin, or adipose, umbilical cord, and placental tissues. Although the first MSCs clinical trials in BPD are ongoing, multiple questions remain open. In this review, we discuss the question of the optimal cell source (live cells or cell products), route and timing of the transplantation. Furthermore, we discuss MSCs possible capacities including migration, homing, proangiogenesis, anti-inflammatory, and tissue-regenerative potential as well.
\end{abstract}

(C) 2016 Published by Elsevier Ltd.

\section{INTRODUCTION}

One of the most complex multifactorial syndromes is preterm birth and, not surprisingly, the leading cause of death in newborns and children $[1,2]$. Despite advances in perinatology, immature

\footnotetext{
* Corresponding author. Maastricht University Medical Center, Department of Pediatrics, P. Debyelaan 25, 6202 AZ Maastricht, The Netherlands.

Tel.: +31 43387 4202; fax: +31433875246.

E-mail addresses: martin.mueller@insel.ch (M. Mueller), b.kramer@maastrichtuniversity.nl (B.W. Kramer).
}

infants continue to face serious risks during pregnancy, parturition and adaptation after birth. Advances in perinatal care have reduced mortality but morbidity still represents a major burden which is evident in very low gestational age infants $(<32$ weeks gestation) $[3,4]$. The magnitude of this burden to both society and family is enormous. Besides prematurity related cerebral morbidities including spastic cerebral palsy and behavioral deficits $[5,6]$, approximately $25 \%$ of immature infants are confronted with long-lasting consequences such as chronic respiratory impairment in the form of bronchopulmonary dysplasia (BPD) [7]. Changes in clinical management have reduced the incidence 
of BPD significantly, with a shift towards extreme low gestational age newborns developing BPD. Thus nowadays, the pathogenesis of BPD is as a developmental disorder consisting of immaturity and impaired alveolar and capillary development leading to incomplete regeneration of the lung [8].

The basic concept of stem cell administration is the prevention of BPD. However, BPD is a term which is currently used to describe the chronic problems of preterm infants that survived up to 36 weeks post menstrual age, [PMA] [9]. In other words BPD is based on a single time point in the continuum of disease and does not take into account the babies that have already died because of lung problems. The time point of 36 weeks PMA is questionable with respect to its predictive value for the future risk and retrospective value in omitting newborns that may have already died of more severe lung disease. The clinical management of BPD in the perinatal period is focused on gas exchange. However, it is not the most common problem. The pathogenesis of BPD is driven by chronic inflammation in the airways which may have its origin antenatally. Further, postnatal triggers such as mechanical ventilation, sepsis, and oxygen toxicity may sustain and aggravate the existing pulmonary inflammation [10]. Since systemic steroids modulate inflammation in the airways, but have detrimental side effects, a local approach would seem preferable. For example, the local application of glucocorticoids has been tested with encouraging effects [11].

In very general terms, we have to consider the development of BPD as an imbalance of chronic injury and incomplete resolution of inflammation coupled with imperfect repair/regeneration. In the context of a lung developing outside the uterus, it is an environment of high oxygen exposure, mechanical stress, and sepsis with a nutritional supply that may be suboptimal. Together, the chronic inflammation may affect both the alveolo- and vasculo-genesis of the developing lung which forms the basis of a disease spectrum that we encounter on the ward and in the outpatient setting.

Although the pathophysiology of the preterm birth syndrome is complex, survivors share morbidities with a common link. It is accepted that inflammatory responses explain the common features of multi-organ injuries in these infants. For example, the initial influx of neutrophils, followed by increased numbers of macrophages, represents the characteristic inflammatory changes in BPD [12]. Further, altered growth factor signaling such as the release of cytokines and disturbance of growth factor signaling is present. One of the key factors is transforming growth factor (TGF)$\beta$ which induces apoptosis [13]. Other examples are angiogenic growth factors, such vascular endothelial growth factor (VEGF) and its receptors, which modulate dysmorphic capillaries and influence the subsequent development of pulmonary hypertension [14]. Additional remodeling or early alveolar epithelial dysfunction promote lung inflammation [15]. Although the pathogenesis of BPD is well defined, current treatment approaches such as supportive therapies in combination with vitamin A and caffeine are insufficient and the results often remain unsatisfactory [16].

Consequently, new therapeutics addressing inflammatory responses and promoting lung regeneration are desperately needed. Mesenchymal stem/stromal cells (MSCs) possess this potential [17]. They were shown to modulate innate and adaptive immune responses, to have anti-apoptotic effects, to decrease inflammation, and to enhance tissue repair, mostly through the release of paracrine factors (Figure 1) $[18,19]$.

\section{STEM CELLS}

Stem cells are defined by their properties with respect to their ability to undergo self-renewal (proliferation) and to give rise to more differentiated cells (differentiation) [17]. Proliferation means the cells renew in principle for an indefinite period. Differentiation implies changing of the cell properties in cells derived from the stem cells. These cells that are no longer stem cells have different functional and phenotypic properties than their parent (stem) cell. The extent of differentiation of cell types in which stem cells can differentiate is called potency [20]. In contrast, totipotent or embryonic stem cells are cells that can differentiate in all cell types, namely into placental and embryonic tissues. Such individual stem

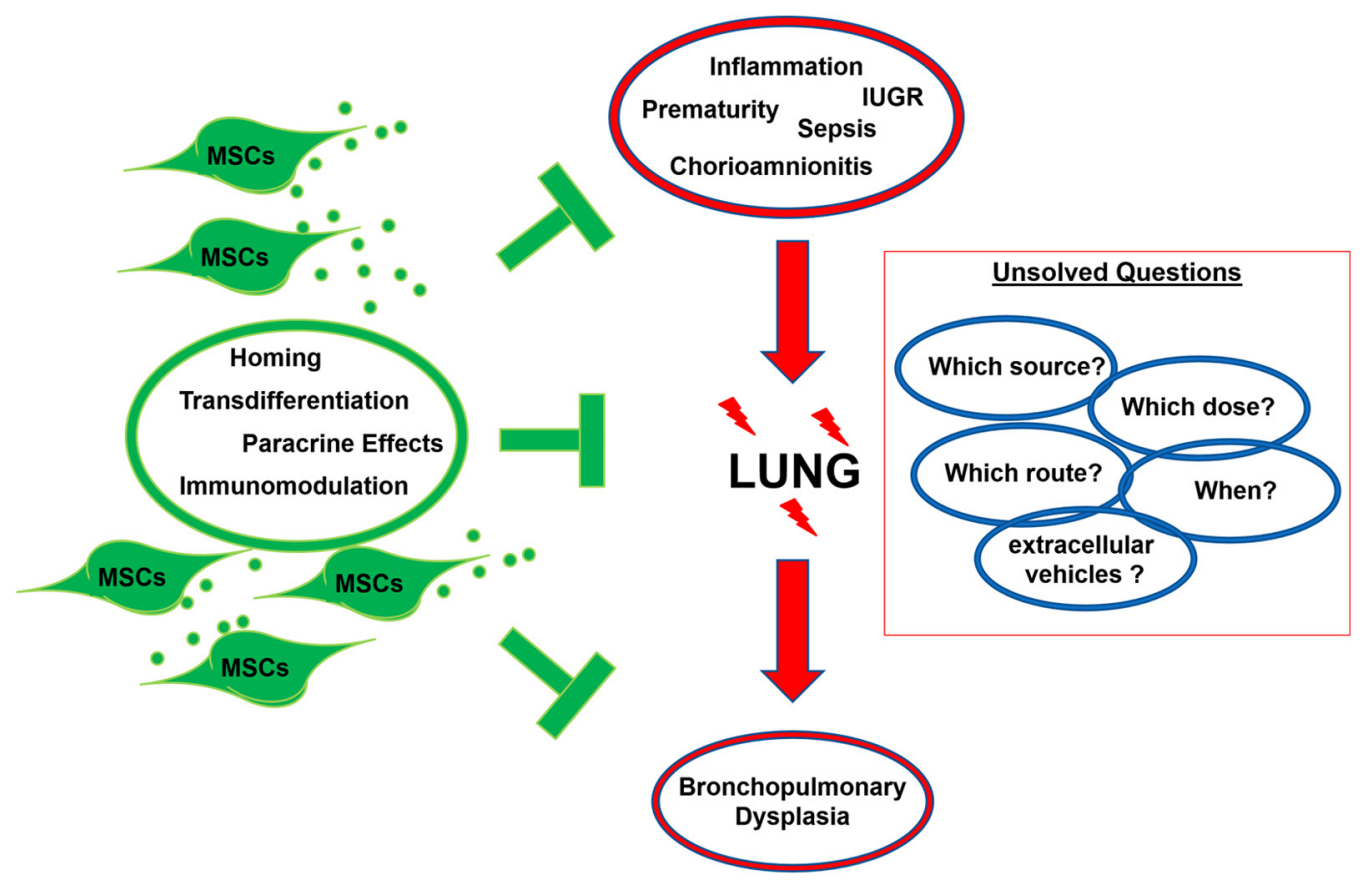

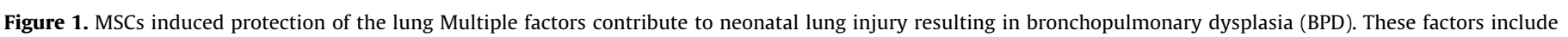

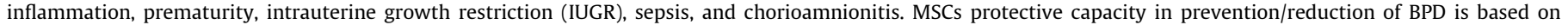

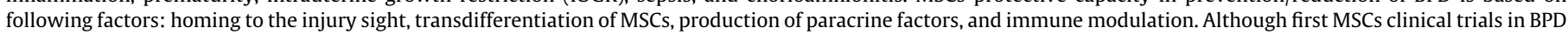
are ongoing, multiple questions remain open: Which MSCs source, at which dose, when, and which route is the optimal one. 
cells can form complete individuals which explains the ethical considerations and limitation around these cells. Stem cells that can give rise to embryonic tissue are called pluripotent stem cells. Multipotent stem cells can differentiate to adult cell types. The best known adult stem cell is probably the hematopoietic stem cell.

\section{MESENCHYMAL STEM/STROMAL CELLS}

Mesenchymal stromal or stem cells are cells that can give rise to tissue types such as cartilage, bone marrow and fat tissue. Stem cells that can differentiate into multipotent MSCs were first described by Friedenstein et al. in 1970 in hematopoietic organs, mainly bone marrow. The term "mesenchymal stem cell" was first used in 1991 by Caplan [21,22]. In recent years clinical and animal studies have focused on mesenchymal stem/stromal cells (MSCs) as a potential cell graft to prevent/repair perinatal acquired injury [17]. MSCs originate from stem cell niches such as bone marrow (BM), skin, or adipose umbilical cord, and placental tissues and therefore are considered somatic stem cells [23]. MSCs must adhere to plastic when cultured in a tissue culture flask and express the surface markers CD73, CD90, and CD105 while lacking expression of CD45, CD34, CD14/CD11b, CD19/CD79 $\alpha$, and HLADR [24] in addition to having potency to differentiate into osteogenic, chondrogenic, and adipogenic lineages. From a clinical point of view, MSCs from placental tissue are of special interest. First, placental tissue provides a broad opportunity to harvest MSCs prenatally or postnatally without ethical concerns and as an autologous source. MSCs can be isolated from placental membranes and tissue [25,26], amniotic fluid [27], umbilical cord blood [28] and umbilical cord connective tissue (Wharton's Jelly) $[29,30]$. Secondly, the predominant causes of preterm birth, such as preeclampsia, have no detrimental impact on the quality of MSCs [31,32]. MSCs are immune-privileged [33]. Finally, MSCs possess the capacity to adapt to the microenvironment of injured organs and therefore, having the heterogeneous pathophysiology of perinatal injuries in mind, MSCs may target multiple organs at once [17].

The next basic problem is the availability of the cells in sufficient numbers at specific time points. The autologous isolation from cord blood, placenta or Wharton's Jelly is an appealing option but raises serious questions [17]. For example, the process must be performed according to good manufacturing practice which implies the careful and time consuming assessment of potential infectious diseases. From a clinical point of view, the more immature the infant, the higher the risk for BPD. However, the most immature infant has the smallest volume of cord blood, smallest placenta and cord size, impacting on the yield of stem cells. Thus, the following questions need to be addressed:

(1) If the number of autologous stem cells is insufficient, can we expand the cells in vitro to obtain the needed numbers?

(2) If we expanded the cells in vitro, under which conditions, and in which time period, should the expansion be completed in order to meet the window of opportunity?

Notably, the autologous production process is not only prone to contamination but also potentially compromised by the loss of the sample which makes the autologous approach rather cumbersome.

\section{MSCS AND BPD}

MSCs based therapies are an attractive strategy since the strategy can potentially replace/restore lost tissue and/or protect/ salvage injured cells. Firstly, clinical MSCs studies addressed the pro-angiogenic, anti-inflammatory, or tissue-regenerative potential in adults [34]. Animal studies confirmed prophylactic and therapeutic MSCs' capacity to ameliorate BPD [35] leading to piloting clinical trials in neonates [36]. This clinical concept was tested in Korea with cells isolated from umbilical cord tissue. The cell populations were expanded in vitro to achieve sufficient cell numbers which were then given "off the shelf" from unrelated donors. In the pilot study, two different doses (in 9 preterm infants at 25 weeks of gestation with a mean birth weight of $790 \mathrm{~g}$ ) via the intratracheal administration route were chosen [36]. This strategy was successful and longer-term follow-up of these pilot patients is proceding. Larger studies testing the clinical feasibility are underway. Nevertheless, questions such as the mode of actions, the desired cell types or products, and the route of transplantation need to be addressed.

MSCs have been successfully studied in both preclinical and clinical studies and in several disorders such as cardiovascular, neurological, haemato-oncological, and auto-inflammatory conditions [34]. The approach of cell graft transplantation developed over the years has led to the first basic question: What type of transplant and application route is appropriate? Basically this concept includes the direct or peripheral transplantation of whole cells, conditioned medium (CM), or purified and defined components of CM (extracellular vehicles: EV). For example, both intratracheal and intravenous administration of BM-MSCs is protective in murine models of BPD [37,38]. Given that the protective effects were attributed in part to paracrine immunomodulation, both BM-MSCs and CM were successful [38]. Other cell sources and both short and long term outcomes were tested as well, showing comparable beneficial results [39]. The question as to whether whole cells or rather cell products are most suitable for BPD remains open and several factors need to be considered. The peripheral approach is based on key properties of MSCs including delivery of the cells "homing" to the site of injury. Interestingly, migration and homing are influenced by multiple factors including age, passage, and number of cells, culture conditions, and delivery method [40]. This migration and homing potential without tumorigenic potential has been described in different disease $[41,42]$ and in BPD models previously $[38,43]$. Chemokines with chemokine receptors CXCR3, CXCR4 and CXCR6 were identified as the key players responsible for cell homing [44]. Further, CXCR4 ligands such as stromal cell-derived factor- $1 \alpha$ (SDF- $1 \alpha)$ promote MSCs' migration to the injury site [45]. Apart from migration and homing, recent studies have focused on cell free approaches such as EV [46]. Multiple vehicles are present in the extracellular space, including shedding vesicles, apoptotic bodies and exosomes. Exosomes (40-100 $\mathrm{nm}$ in diameter) are secreted by cells and may transfer proteins and functional genetic materials (i.e. mRNA and microRNAs). They are involved in cell-to-cell signaling/ regulation [47]. Although this approach is very promising, it is still in its infancy. We also have to consider that stem cells encourage the growth and even supplement (host) cells [48]. Additionally, the immunomodulation potential of MSCs may depend on the bidirectional communication between the injured host cells and the graft [49]. Together multiple transplantation routes and graft types have been successfully tested in diverse injury models including BPD. Regardless of the transplantation route, the basic mode of action is paracrine immunomodulation [17].

\section{MSCS AND MODE OF ACTION}

MSCs response to injury is a crucial advantage over non-cell based therapies. A vast amount of data has originated from adult pulmonary diseases or in-vitro studies. Studies have identified key factors including cytokines, interleukins, and trophic factors predominately involved in angiogenesis, hematopoiesis or neuronal and cardiovascular regeneration [50-52]. Classical examples 
are interleukin-10 and TNF-stimulated gene/protein 6 which both possess anti-inflammatory capacity [33]. Stanniocalcin-1, hepatocyte growth factor (HGF) and vascular endothelial growth factor (VEGF) promote lung development or oxidative stress resistance [53-55]. Importantly, MSCs and/or their secretome have effects well beyond promoting lung regeneration as well as the modulation of immune responses $[38,47]$. For example, MSCs inhibit autoreactive T cell responses and shift the alveolar macrophages from a M1 (proinflammatory) to a M2 (protective) phenotype resulting in reduced pulmonary injury [56]. Besides T-cell modulation [57], MSCs inhibit B cell proliferation, neutrophils and monocytes function, and NK toxicity [58-61]. All these paracrine and immunomodulatory properties are present after both whole cell and cell derived product transplantation. However, differences in treatment outcomes were reported. For example, $\mathrm{CM}$ seems to be inferior in longterm effects but equal or superior in short-term effects compared to whole cell therapy $[38,62]$. Thus, a direct interaction with injured cells may potentiate therapeutic efficacy and in the case of CM or CM products multiple treatments may be appropriate [35,63]. The concept of MSCs sensing, integrating, and responding to the surrounding is intriguing as MSCs potential to replace injured cells is not proven and a matter of constant debate [64-66]. For example, MSCs improve myocardial infarction without permanent replacement after intravenous application [67]. However, these cells embolise and cause endothelial damage in the lung as well [67]. In conclusion, MSCs' low rate of in vivo engraftment and differentiation suggest paracrine immunomodulation, but whether factors released by the MSCs or the cells themselves are the best choice remains an open question. Especially as whole cell transplantation carries risks of tumorigenic potential $[21,22]$ this approach needs to be carefully considered. From a clinical perspective two scenarios are possible: (1) a malignant transformation of the cell transplant itself and (2) an immunosuppressive effect of MSCs, which leads to growth of existing malignant cells in a patient [68]. Notably, the tumourigenic potential of the stem cell is primarily affected by the manufacturing process and the cellular source. For example, the risk of tumourigenic potential is higher for autologous cells due to slower or absent clearance by the immune system after transplantation [68]. Although no malignant tumourigenic transformation has been previously reported, the potential for transformation must be further explored and monitored in a clinical setting with long follow-up period, especially as treatments is initiated in immature infants. Additional studies addressing the long term impact on the immune system needs to be addressed as well.

\section{SUMMARY}

In summary, MSCs represent new potent therapeutic options to treat multiple disorders associated with preterm birth including BPD. Given that BPD is a developmental disorder with deregulated inflammatory responses, MSCs primary mode of action is to modulate innate and adaptive immunity and decrease inflammation while enhancing tissue repair (Figure 1). While autologous MSCs such as placental tissue are easy available without ethical concerns, the question of sufficient cell number and availability at specific time point remains unanswered. Thus, the concept of cell products such as conditioned media or purified and defined components of condition media (extracellular vehicles) has emerged recently. The protective paracrine and immunomodulatory properties are present after both whole cell and cell derived product transplantation but several questions remain unanswered. Since whole cells may provide a direct interaction with injured cells, cell derived products may require multiple treatments. However, as whole cell transplantation carries risks of tumourigenic potential, this approach needs to be carefully considered. Future basic and clinical research needs to address following the knowledge gaps: the optimal cell source (autologous versus allogenic), cell type (whole cells in which status versus cell derived products), cell dose (single versus multiple), transplantation route (intratracheal versus peripheral), and finally the patient population.

\section{DIRECTIONS FOR FUTURE RESEARCH}

Carefully designed studies with long term follow-up need to give the answers to the essential five questions:

- Which cells have to be given,

- when,

- in which dose,

- to which patients

- via which route?

\section{References}

[1] Phillips JB, Abbot P, Rokas A. Is preterm birth a human-specific syndrome? Evol Med Public Health 2015;2015(1):136-48. http://dx.doi.org/10.1093/emph/ eov010

[2] Liu L, Oza S, Hogan D, Perin J, Rudan I, Lawn JE, et al. Global, regional, and national causes of child mortality in 2000-13, with projections to inform post2015 priorities: an updated systematic analysis. Lancet 2015;385(9966):43040. http://dx.doi.org/10.1016/S0140-6736(14)61698-6

[3] Numerato D, Fattore G, Tediosi F, Zanini R, Peltola M, Banks H, et al. Mortality and length of stay of very low birth weight and very preterm infants: a EuroHOPE study. PLoS One 2015;10(6):e0131685. http://dx.doi.org/10.1371/ journal.pone.0131685

[4] Schaaf JM, Mol BW, Abu-Hanna A, Ravelli AC. Trends in preterm birth: singleton and multiple pregnancies in the Netherlands, 2000-2007. BJOG 2011;118(10):1196-204. http://dx.doi.org/10.1111/j.1471-0528.2011.03010.x

[5] Hamrick SE, Miller SP, Leonard C, Glidden DV, Goldstein R, Ramaswamy V, et al. Trends in severe brain injury and neurodevelopmental outcome in premature newborn infants: the role of cystic periventricular leukomalacia. J Pediatr 2004;145(5):593-9. http://dx.doi.org/10.1016/j.jpeds.2004.05.042

[6] Larroque B, Ancel PY, Marret S, Marchand L, Andre M, Arnaud C, et al. Neurodevelopmental disabilities and special care of 5-year-old children born before 33 weeks of gestation (the EPIPAGE study): a longitudinal cohort study. Lancet 2008;371(9615):813-20. http://dx.doi.org/10.1016/S0140-6736(08)60380-3

[7] Jensen EA, Schmidt B. Epidemiology of bronchopulmonary dysplasia. Birth Defects Res A Clin Mol Teratol 2014;100(3):145-57. http://dx.doi.org/10.1002/ bdra.23235

[8] Van Marter LJ. Epidemiology of bronchopulmonary dysplasia. Semin Fetal Neonatal Med 2009;14(6):358-66. http://dx.doi.org/10.1016/j.siny.2009.08.007

[9] Jobe AH, Bancalari E. Bronchopulmonary dysplasia. Am J Respir Crit Care Med 2001;163(7):1723-9. http://dx.doi.org/10.1164/ajrccm.163.7.2011060

[10] Rivera L, Siddaiah R, Oji-Mmuo C, Silveyra GR, Silveyra P. Biomarkers for bronchopulmonary dysplasia in the preterm infant. Front Pediatr 2016;4:33. http://dx.doi.org/10.3389/fped.2016.00033

[11] Yeh TF, Chen CM, Wu SY, Husan Z, Li TC, Hsieh WS, et al. Intratracheal administration of budesonide/surfactant to prevent bronchopulmonary dysplasia. Am J Respir Crit Care Med 2016;193(1):86-95. http://dx.doi.org/ 10.1164/rccm.201505-08610C

[12] Speer CP. Pulmonary inflammation and bronchopulmonary dysplasia. J Perinatol 2006;26(Suppl 1):S57-62. http://dx.doi.org/10.1038/sj.jp.7211476. discussion S63-54.

[13] Kunzmann S, Speer CP, Jobe AH, Kramer BW. Antenatal inflammation induced TGF-beta1 but suppressed CTGF in preterm lungs. Am J Physiol Lung Cell Mol Physiol 2007;292(1):L223-31. http://dx.doi.org/10.1152/ajplung.00159.2006

[14] Thebaud B. Angiogenesis in lung development, injury and repair: implications for chronic lung disease of prematurity. Neonatology 2007;91(4):291-7. http://dx.doi.org/10.1159/000101344

[15] Atochina-Vasserman EN, Bates SR, Zhang P, Abramova H, Zhang Z, Gonzales L, et al. Early alveolar epithelial dysfunction promotes lung inflammation in a mouse model of Hermansky-Pudlak syndrome. Am J Respir Crit Care Med 2011;184(4):449-58. http://dx.doi.org/10.1164/rccm.201011-18820C

[16] Donohue PK, Gilmore MM, Cristofalo E, Wilson RF, Weiner JZ, Lau BD, et al. Inhaled nitric oxide in preterm infants: a systematic review. Pediatrics 2011;127(2):e414-22. http://dx.doi.org/10.1542/peds.2010-3428

[17] Mueller M, Wolfs TG, Schoeberlein A, Gavilanes AW, Surbek D, Kramer BW. Mesenchymal stem/stromal cells-a key mediator for regeneration after perinatal morbidity? Mol Cell Pediatr 2016;3(1):6. http://dx.doi.org/10.1186/ s40348-016-0034-X

[18] Lee JW, Fang X, Krasnodembskaya A, Howard JP, Matthay MA. Concise review: mesenchymal stem cells for acute lung injury: role of paracrine soluble factors. Stem Cells 2011;29(6):913-9. http://dx.doi.org/10.1002/stem.643

[19] Phillips AW, Johnston MV, Fatemi A. The potential for cell-based therapy in perinatal brain injuries. Transl Stroke Res 2013;4(2):137-48. http://dx.doi.org/ 10.1007/s12975-013-0254-5 
[20] Hilgendorff A, O'Reilly MA. Bronchopulmonary dysplasia early changes leading to long-term consequences. Front Med (Lausanne) 2015;2:2. http:/ dx.doi.org/10.3389/fmed.2015.00002

[21] Ramalho-Santos M, Willenbring H. On the origin of the term "stem cell". Cell Stem Cell 2007;1(1):35-8. http://dx.doi.org/10.1016/j.stem.2007.05.013

[22] Caplan AI. Mesenchymal stem cells. J Orthop Res 1991;9(5):641-50. http:// dx.doi.org/10.1002/jor.1100090504

[23] Zuk PA, Zhu M, Mizuno H, Huang J, Futrell JW, Katz AJ, et al. Multilineage cells from human adipose tissue: implications for cell-based therapies. Tissue Eng 2001;7(2):211-28. http://dx.doi.org/10.1089/107632701300062859

[24] Dominici M, Le Blanc K, Mueller I, Slaper-Cortenbach I, Marini F, Krause D, et al. Minimal criteria for defining multipotent mesenchymal stromal cells. The International Society for Cellular Therapy position statement. Cytotherapy 2006;8(4):315-7. http://dx.doi.org/10.1080/14653240600855905

[25] In 't Anker PS, Scherjon SA, Kleijburg-van der Keur C, de Groot-Swings GM Claas FH, Fibbe WE, et al. Isolation of mesenchymal stem cells of fetal or maternal origin from human placenta. Stem Cells 2004;22(7):1338-45. http:// dx.doi.org/10.1634/stemcells.2004-0058

[26] Igura K, Zhang X, Takahashi K, Mitsuru A, Yamaguchi S, Takashi TA. Isolation and characterization of mesenchymal progenitor cells from chorionic villi of human placenta. Cytotherapy 2004;6(6):543-53.

[27] Stefanidis K, Loutradis D, Anastasiadou V, Bletsa R, Kiapekou E, Drakakis P, et al Oxytocin receptor- and Oct-4-expressing cells in human amniotic fluid. Gynecol Endocrinol 2008;24(5):280-4. http://dx.doi.org/10.1080/09513590801977167

[28] Erices A, Conget P, Minguell JJ. Mesenchymal progenitor cells in human umbilical cord blood. Br J Haematol 2000;109(1):235-42.

[29] Ma L, Feng XY, Cui BL, Law F, Jiang XW, Yang LY, et al. Human umbilical cord Wharton's Jelly-derived mesenchymal stem cells differentiation into nervelike cells. Chin Med J (Engl) 2005;118(23):1987-93.

[30] Wang HS, Hung SC, Peng ST, Huang CC, Wei HM, Guo YJ, et al. Mesenchymal stem cells in the Wharton's jelly of the human umbilical cord. Stem Cells 2004;22(7):1330-7. http://dx.doi.org/10.1634/stemcells.2004-0013

[31] Sibai B, Dekker G, Kupferminc M. Pre-eclampsia. Lancet 2005;365(9461):78599. http://dx.doi.org/10.1016/S0140-6736(05)17987-2

[32] Messerli M, Wagner A, Sager R, Mueller M, Baumann M, Surbek DV, et al. Stem cells from umbilical cord Wharton's jelly from preterm birth have neuroglia differentiation potential. Reprod Sci 2013;20(12):1455-64. http://dx.doi.org 10.1177/1933719113488443

[33] Fontaine MJ, Shih H, Schafer R, Pittenger MF. Unraveling the mesenchymal stromal cells' paracrine immunomodulatory effects. Transfus Med Rev 2016;30(1):37-43. http://dx.doi.org/10.1016/j.tmrv.2015.11.004

[34] Lalu MM, McIntyre L, Pugliese C, Fergusson D, Winston BW, Marshall JC, et al. Safety of cell therapy with mesenchymal stromal cells (SafeCell): a systematic review and meta-analysis of clinical trials. PLoS One 2012;7(10):e47559. http://dx.doi.org/10.1371/journal.pone.0047559

[35] Pierro M, Ciarmoli E, Thebaud B. Bronchopulmonary dysplasia and chronic lung disease: stem cell therapy. Clin Perinatol 2015;42(4):889-910. http:// dx.doi.org/10.1016/j.clp.2015.08.013

[36] Chang YS, Ahn SY, Yoo HS, Sung SI, Choi SJ, Oh WI, et al. Mesenchymal stem cells for bronchopulmonary dysplasia: phase 1 dose-escalation clinical trial. J Pediatr 2014;164(5):966-72. http://dx.doi.org/10.1016/j.jpeds.2013.12.011. e966.

[37] van Haaften T, Byrne R, Bonnet S, Rochefort GY, Akabutu J, Bouchentouf M, et al. Airway delivery of mesenchymal stem cells prevents arrested alveolar growth in neonatal lung injury in rats. Am I Respir Crit Care Med 2009;180(11):1131-42. http://dx.doi.org/10.1164/rccm.200902-01790C

[38] Aslam M, Baveja R, Liang OD, Fernandez-Gonzalez A, Lee C, Mitsialis SA, et al. Bone marrow stromal cells attenuate lung injury in a murine model of neonatal chronic lung disease. Am J Respir Crit Care Med 2009;180(11):1122-30. http:/ dx.doi.org/10.1164/rccm.200902-02420C

[39] Pierro M, Ionescu L, Montemurro T, Vadivel A, Weissmann G, Oudit G, et al. Short-term, long-term and paracrine effect of human umbilical cord-derived stem cells in lung injury prevention and repair in experimental bronchopulmonary dysplasia. Thorax 2013;68(5):475-84. http://dx.doi.org/10.1136/ thoraxjnl-2012-202323

[40] Sohni A, Verfaillie CM. Mesenchymal stem cells migration homing and tracking. Stem Cells Int 2013;2013:130763. http://dx.doi.org/10.1155/2013/130763

[41] Prasad VK, Kurtzberg J. Umbilical cord blood transplantation for non-malig nant diseases. Bone Marrow Transplant 2009;44(10):643-51. http://dx.doi.org/ $10.1038 /$ bmt.2009.290

[42] Schoeberlein A, Mueller M, Reinhart U, Sager R, Messerli M, Surbek DV. Homing of placenta-derived mesenchymal stem cells after perinatal intracerebral transplantation in a rat model. Am J Obstet Gynecol 2011;205(3):277. http://dx.doi.org/10.1016/j.ajog.2011.06.044. e271-276.

[43] Zhang X, Wang H, Shi Y, Peng W, Zhang S, Zhang W, et al. Role of bone marrowderived mesenchymal stem cells in the prevention of hyperoxia-induced lung injury in newborn mice. Cell Biol Int 2012;36(6):589-94. http://dx.doi.org/ 10.1042/CBI20110447

[44] Yang JX, Zhang N, Wang HW, Gao P, Yang QP, Wen QP. CXCR4 receptor overexpression in mesenchymal stem cells facilitates treatment of acute lung injury in rats. J Biol Chem 2015;290(4):1994-2006. http://dx.doi.org/10.1074/ jbc.M114.605063

[45] Yang DY, Sheu ML, Su HL, Cheng FC, Chen YJ, Chen CJ, et al. Dual regeneration of muscle and nerve by intravenous administration of human amniotic fluidderived mesenchymal stem cells regulated by stromal cell-derived factor1 alpha in a sciatic nerve injury model. I Neurosurg 2012;116(6):1357-67. http://dx.doi.org/10.3171/2012.2.JNS111360
[46] Katsuda T, Kosaka N, Takeshita F, Ochiya T. The therapeutic potential of mesenchymal stem cell-derived extracellular vesicles. Proteomics 2013;13(10-11):1637-53. http://dx.doi.org/10.1002/pmic.201200373

[47] Bruno S, Deregibus MC, Camussi G. The secretome of mesenchymal stromal cells: role of extracellular vesicles in immunomodulation. Immunol Lett 2015. http://dx.doi.org/10.1016/j.imlet.2015.06.007

[48] Glenn JD, Whartenby KA. Mesenchymal stem cells: emerging mechanisms of immunomodulation and therapy. World J Stem Cells 2014;6(5):526-39. http:// dx.doi.org/10.4252/wjsc.v6.i5.526

[49] Pluchino S, Cossetti C. How stem cells speak with host immune cells in inflammatory brain diseases. Glia 2013;61(9):1379-401. http://dx.doi.org/ 10.1002 /glia.22500

[50] Fung ME, Thebaud B. Stem cell-based therapy for neonatal lung disease: it is in the juice. Pediatr Res 2014;75(1-1):2-7. http://dx.doi.org/10.1038/pr.2013.176

[51] Hsieh JY, Wang HW, Chang SJ, Liao KH, Lee IH, Lin WS, et al. Mesenchymal stem cells from human umbilical cord express preferentially secreted factors related to neuroprotection, neurogenesis, and angiogenesis. PLoS One 2013;8(8):e72604. http://dx.doi.org/10.1371/journal.pone.0072604

[52] Gao LR, Zhang NK, Ding QA, Chen HY, Hu X, Jiang S, et al. Common expression of stemness molecular markers and early cardiac transcription factors in human Wharton's jelly-derived mesenchymal stem cells and embryonic stem cells. Cell Transplant 2013;22(10):1883-900. http://dx.doi.org/10.3727/ 096368912 X662444

[53] Chang YS, Ahn SY, Jeon HB, Sung DK, Kim ES, Sung SI, et al. Critical role of vascular endothelial growth factor secreted by mesenchymal stem cells in hyperoxic lung injury. Am J Respir Cell Mol Biol 2014;51(3):391-9. http:// dx.doi.org/10.1165/rcmb.2013-03850C

[54] Waszak P, Alphonse R, Vadivel A, Ionescu L, Eaton F, Thebaud B. Preconditioning enhances the paracrine effect of mesenchymal stem cells in preventing oxygeninduced neonatal lung injury in rats. Stem Cells Dev 2012;21(15):2789-97. http://dx.doi.org/10.1089/scd.2010.0566

[55] Meng F, Meliton A, Moldobaeva N, Mutlu G, Kawasaki Y, Akiyama T, et al. Asef mediates HGF protective effects against LPS-induced lung injury and endothelial barrier dysfunction. Am J Physiol Lung Cell Mol Physiol 2015;308(5):L452-63. http://dx.doi.org/10.1152/ajplung.00170.2014

[56] Maron-Gutierrez T, Silva JD, Asensi KD, Bakker-Abreu I, Shan Y, Diaz BL, et al. Effects of mesenchymal stem cell therapy on the time course of pulmonary remodeling depend on the etiology of lung injury in mice. Crit Care Med 2013;41(11):e319-33. http://dx.doi.org/10.1097/CCM.0b013e31828a663e

[57] Di Nicola M, Carlo-Stella C, Magni M, Milanesi M, Longoni PD, Matteucci P, et al. Human bone marrow stromal cells suppress T-lymphocyte proliferation induced by cellular or nonspecific mitogenic stimuli. Blood 2002;99(10):3838-43.

[58] Franquesa M, Hoogduijn MJ, Bestard O, Grinyo JM. Immunomodulatory effect of mesenchymal stem cells on B cells. Front Immunol 2012;3:212. http:// dx.doi.org/10.3389/fimmu.2012.00212

[59] Raffaghello L, Bianchi G, Bertolotto M, Montecucco F, Busca A, Dallegri F, et al. Human mesenchymal stem cells inhibit neutrophil apoptosis: a model for neutrophil preservation in the bone marrow niche. Stem Cells 2008;26(1):15162. http://dx.doi.org/10.1634/stemcells.2007-0416

[60] Ivanova-Todorova E, Bochev I, Mourdjeva M, Dimitrov R, Bukarev D, Kyurkchiev $\mathrm{S}$, et al. Adipose tissue-derived mesenchymal stem cells are more potent suppressors of dendritic cells differentiation compared to bone marrowderived mesenchymal stem cells. Immunol Lett 2009;126(1-2):37-42. http://dx.doi.org/10.1016/j.imlet.2009.07.010

[61] Spaggiari GM, Capobianco A, Abdelrazik H, Becchetti F, Mingari MC, Moretta L. Mesenchymal stem cells inhibit natural killer-cell proliferation, cytotoxicity, and cytokine production: role of indoleamine 2,3-dioxygenase and prostaglandin E2. Blood 2008;111(3):1327-33. http://dx.doi.org/10.1182/blood2007-02-074997

[62] Sutsko RP, Young KC, Ribeiro A, Torres E, Rodriguez M, Hehre D, et al. Longterm reparative effects of mesenchymal stem cell therapy following neonatal hyperoxia-induced lung injury. Pediatr Res 2013;73(1):46-53. http:// dx.doi.org/10.1038/pr.2012.152

[63] Islam MN, Das SR, Emin MT, Wei M, Sun L, Westphalen K, et al. Mitochondrial transfer from bone-marrow-derived stromal cells to pulmonary alveoli protects against acute lung injury. Nat Med 2012;18(5):759-65. http://dx.doi.org/ $10.1038 / \mathrm{nm} .2736$

[64] Uccelli A, Benvenuto F, Laroni A, Giunti D. Neuroprotective features of mesenchymal stem cells. Best Pract Res Clin Haematol 2011;24(1):59-64. http:// dx.doi.org/10.1016/j.beha.2011.01.004

[65] Bianco P, Cao X, Frenette PS, Mao JJ, Robey PG, Simmons PJ, et al. The meaning the sense and the significance: translating the science of mesenchymal stem cells into medicine. Nat Med 2013;19(1):35-42. http://dx.doi.org/10.1038/ $\mathrm{nm} .3028$

[66] Kotton DN, Morrisey EE. Lung regeneration: mechanisms, applications and emerging stem cell populations. Nat Med 2014;20(8):822-32. http:// dx.doi.org/10.1038/nm.3642

[67] Lee RH, Pulin AA, Seo MJ, Kota DJ, Ylostalo J, Larson BL, et al. Intravenous hMSCs improve myocardial infarction in mice because cells embolized in lung are activated to secrete the anti-inflammatory protein TSG-6. Cell Stem Cell 2009;5(1):54-63. http://dx.doi.org/10.1016/j.stem.2009.05.003

[68] Barkholt L, Flory E, Jekerle V, Lucas-Samuel S, Ahnert P, Bisset L, et al. Risk of tumorigenicity in mesenchymal stromal cell-based therapies-bridging scientific observations and regulatory viewpoints. Cytotherapy 2013;15(7):753-9. http://dx.doi.org/10.1016/j.jcyt.2013.03.005 


\section{EDUCATIONAL ARTICLE}

You can receive $1 \mathrm{CME}$ credit by successfully answering these questions online.

(A) Visit the journal CME site at http://www.prrjournal.com.

(B) Complete the answers online, and receive your final score upon completion of the test.

(C) Should you successfully complete the test, you may download your accreditation certificate (subject to an administrative charge), accredited by the European Board for Accreditation in Pneumology.

\section{CME MCQ QUESTIONS}

1) Bronchopulmonary dysplasia is defined as:
a. 35-37 weeks PMA inclusive
b. 36-37 weeks PMA inclusive
c. 36-38 weeks PMA inclusive
d. Degree of oxygen need/respiratory support at a certain age
e. 37-39 weeks PMA inclusive

2) Which of the following is true regarding stem cells?
a. Ethical dilemmas make their use almost impossible
b. Stem cells are defined by their proliferation and differen- tiation
c. Stem cells are an academic myth to generate research funds

d. Stem cells are useless outside the womb

e. Stem cells can only be used on the donor

3) Which of the following is true regarding sources of mesenchymal stem cells?

a. Mesenchymal stem cells are a commodity, traded in large quantities and in consistent quality

b. Mesenchymal stem cells can only be harvested from embryos

c. Mesenchymal stem cells can be isolated from different tissues

d. Mesenchymal stem cells can be isolated only from the mother of the baby

e. Mesenchymal stem cells can give rise to embryonic tissues such as placenta

4) Which difficulties may arise when using MSCs from an autologous source?

a. Insufficient numbers of cells

b. Cells not available at a specific time point

c. Cells are contaminated

d. Placenta can't be used because it is embryonic tissue

e. Loss of sample

5) Which of the following properties is not proposed MSCs' mode of action in BPD models?

a. anti-inflammatory

b. inflammatory

c. paracrine

d. homing

e. migration 